\title{
"Memada-mada": The Power Relation and Architectural Creativity of Gianyar Palace
}

\author{
Ida Bagus Gde Wirawibawa, I Dewa Gede Agung Diasana Putra*, Ngakan Ketut Acwin Dwijendra \\ Department of Architecture, Faculty of Engineering, Udayana University, Badung, 80361, Bali, Indonesia
}

Received March 4, 2021; Revised April 20, 2021; Accepted May 16, 2021

\section{Cite This Paper in the following Citation Styles}

(a): [1] Ida Bagus Gde Wirawibawa, I Dewa Gede Agung Diasana Putra, Ngakan Ketut Acwin Dwijendra, "'Memada-mada": The Power Relation and Architectural Creativity of Gianyar Palace," Civil Engineering and Architecture, Vol. 9, No. 3, pp. 949 - 957, 2021. DOI: 10.13189/cea.2021.090336.

(b): Ida Bagus Gde Wirawibawa, I Dewa Gede Agung Diasana Putra, Ngakan Ketut Acwin Dwijendra (2021). "Memada-mada": The Power Relation and Architectural Creativity of Gianyar Palace. Civil Engineering and Architecture, 9(3), 949 - 957. DOI: 10.13189/cea.2021.090336.

Copyright $\bigcirc 2021$ by authors, all rights reserved. Authors agree that this article remains permanently open access under the terms of the Creative Commons Attribution License 4.0 International License

\begin{abstract}
Balinese royal palaces' forms illustrate the evolving nature of the kingdom's political control and the strategies used by its rulers to foster the stability of its territory. Although every kingdom has opportunities to demonstrate its authority through architecture and layout, architectural hierarchy is presented from the form of architectural productions, including the traditional gate called kori agung among palaces called puris, especially the architectural form in palaces of Gianyar. This phenomenon has risen to the questions on how far the authority power influences the architectural form. Are there any other elements that influence the architectural form design in Gianyar? Drawing from seventeenththrough twentieth-century photographs, correspondences and collected oral traditions, this paper explores the oral traditions and power relationships among the kingdoms that influence the layout and form of the palace's architectural production called puri in Gianyar Bali. This paper found that the phrase "memada-mada" has influenced the architecture of palaces in Gianyar, especially the kori agung. The term refers to attempting to avoid performing the same or greater acts as those with a higher status.
\end{abstract}

Keywords Local Oral Tradition, Power Relation, Architectural Form, Puri, Hierarchy

\section{Introduction}

Architectural productions have been valuable archives of civilization history since the buildings, under a political authority, have represented social-cultural, economic and political status [1]. Political institution demonstrating "the moral rightness or superiority of an institution" has influenced the creation of new traditions in order to demonstrate its power [2]. An authority's power can be read by observing architectural practices components, including shape, scale, style, detail and ornamentation [3], [4]. Political authorities often built majestic structures, palaces and monuments, in their territory to show their power [5]. However, far from presenting their power status totally by monumental architecture productions of palaces to demonstrate their power in their territory, other aspects influence the decision to design the architectural form and layout. This phenomenon is an interesting architectural phenomenon. On one side, a power authority presents its power by constructing monumental architecture to create an identity and present its power more than the other. However, Puri Gianyar, one of Bali's most influential kingdoms demonstrates humble architectural forms in its palace to respect other architectural functions. 
Balinese architectural principles are derived from a social and cosmological system. This system focuses on the symbolical meaning and hierarchy of space [6]. This cosmological system is influenced by the spiritual belief that produces local wisdom in the Balinese daily life. Some of the local wisdom is derived from oral history that has been used as Balinese moral ethics. Moral ethics in a community as a pearl of local wisdom in Bali, including memada-mada, is usually related to history, especially Bali's oral history believed by Balinese to influence their life. Based on Balinese language, memada-mada means being equal, so in this context, memada-mada is related that people should not do something equivalent to a higher status. This practice is a moral ethic for Balinese in their daily lives that becomes a pearl of local wisdom performed for centuries, especially in the precolonial era. Balinese people believe that a moral ethic is born from past events told orally and are questioned by the community for the truth. This faith could be in the form of belief in curses from or reverence for God or a highly respected leader. Balinese people from generation still carry out a tradition related to ethical morals, which is often a legacy of feudalism [7].

Memada-mada is related to the curse of women that deliver twin babies. The twin babies that are a boy and a girl called kembar buncing, are believed as a curse for a commoner family. The phrase "memada-mada" has also been used in many Balinese life aspects such as people behaviour and architecture. It is interesting to explore how far this phrase is applied in architectural productions especially in a palace called puri. The architectural production of the palace is closely related to the nuances of political power. This phenomenon becomes paradoxical since the local moral ethic is related to a way of life to be humble in front of others. In contrast political power is the way to present more power than others.

\section{Materials and Methods}

This paper investigates the architectural form of puris in Gianyar compared with the architectural form of the puri Klungkung to identify how far the contestation of power relation in Bali has influenced the architectural form of puris in Gianyar. This paper studies various topics and collects data by using qualitative and quantitative methods. To research and investigate the authority power to produce architectural identity, a tiered method involving essential data collection, in-depth investigation and examination of puris' forms and layout, interviews, and architectural documentation, was conducted. The kori agungs were measured using a theodolite to get their size and proportion. Comparative analysis was then used to investigate the influence of political power and moral ethic wisdom to the form of the kori agungs.

The paper begins by defining the theories and key concepts and then researching previous studies. In this paper, the comparison of architectural traditions of puris and political power contestation in Gianyar Bali is the way to analyse the correlation between architecture, political power and the Balinese modal ethic. In this method, the field data collection begins with the investigation of primary data on the layout and form of buildings in puris of Gianyar. The mapping of the layout and form, including the proportion and the scale of buildings in palaces, is essential for further investigation. The information and analyses of literature, old photographs, and spatial stories from royal families are essential to explore the relationship between power relations, moral ethics, local wisdom, and buildings' architectural form.

\section{Memada-mada: The Moral Ethic Wisdom of Balinese People}

The term of memada-mada is a further explanation of the manak salah's termsthat then becomes related to various aspects of community life, including architecture. The terms of manak salah has existed since the $12^{\text {th }}$ century when Jaya Pangus ruled Bali in Balingkang around Kintamani Bangli. In the 12th century, having twins of different genders, called kembar buncing, was common among the royal family. The births of kembar buncing were considered a blessing from God or ancestors in which people believed that the new leaders had already be born [8].

In historical records, mostly oral history in the area around Kintamani, Bangli, the twin babies' mother is Kang Ching Whi, a Chinese woman. She was a very beautiful girl who was married as a second wife by Jaya Pangus, and the king also had a very beautiful wife who lives in Songan, called Dewi Danuh. Based on the Balinese people belief, the kembar buncing became an influential leader. This belief has been confirmed when the twins became famous king of Bali, well known as the King of Masula and Masuli [9].

Meanwhile, if the kembar buncing occurred to ordinary people, the kembar buncing was said to be wrong and was considered to bring disaster. The king issued this statement in such a way to ensure that his position could not be equated to that of the ordinary people called memada-mada. The purpose of implementing this rule was to maintain the position or authority of a king [8], [9]. The king ordered every people that having twin babies of different genders should be exiled to the edge of the village. After that, the people performed the ceremony called the manak salah.

Therefore, from a historical aspect, manak salah is related to memada-mada. This term refers to the Balinese wisdom of not attempting to create something equivalent to the king, particularly in relation to having the kembar 
buncing babies. The phrase of memada-mada is then used in many Balinese life aspects to remind people not to be equal with kings or royal family or the people with higher social status. This phrase has become moral guidance for Balinese to express their behaviour in their communities. This practice represents that in Balinese life, hierarchy and strata become a part of Balinese traditions from the social strata into the spatial order.

\section{Hierarchy in the Balinese Architecture}

Traditional Balinese architectures, including the traditional houses that have experienced transformation in political tourism agenda [10], [11], have been created based on the traditional social strata in the Balinese community. In these social strata, warna or caste system consisting of brahmana, satria, wesia and sudra creates a hierarchical division of society into four categories [12] [15]. This system is related to various title groups called soroh in which the title is patrilineal inheritance. The first three warnas are grouped as triwangsa representing around $6-10 \%$ of the Balinese population. On the other hand, sudra, which was labelled commoners, is accounted for as the rest [12]. The categories are based on obligations, talents, or occupations. Brahmana is a class of society that is obliged in religion and development science, such as priests and clergy. The second warna is when a group of people is obliged to government and military fields, such as kings, soldiers or officials. This group is called ksatrya. Wesya is an obligatory group of people in the field of community welfare, such as traders. Sudra is a group of people obliges to help brahman, ksatrya, and wesya groups, such as workers and labourers [16].

Each of these community groups has a different variety of housing, according to their function and position in society. Puri is a house for ksatrya group (kings and their families), while geria is a house for brahmana group (clergy and their families). Jero is a house for ksatrya (retainer or those who do not hold power) and wesya (aristocrats and their families). The last is umah that is a house for sudra group [17]. Besides the spatial orientation and geography condition [18]-[21], this caste system influences the Balinese settlement's spatial layout. In this system, the spaces are divided into three-layer concentric circles according to the level of the group communities that inhabit each of these layers in which puri has the primary value; geria and jero are of intermediate value, and umah has a disgraceful value [22]. The sudra house dimension is relatively smaller, and its spatial layout is simpler than the triwangsa's house. This caste hierarchy is also related to the building types and materials [23]. As the highest authority and government, the king and his family's house called puri is located in the main intersection called catuspatha areas or pempatan agung. This area is seen as the sacred and the centre of the world, thus becoming the main area. Jero and geria that are the houses for triwangsa are located around puri. On the other hand, sudra's house is located on the outskirts of the centre area [22]. This spatial zonation is related to the philosophy of the traditional Balinese architecture.

The Balinese architecture forms that are an important part of the cultural landscape of Bali [18] are perceived as the mediator of a world divided into two opposing poles, the forces of God that is the sacred spaces and the nether as the profane, an area for purifying [24], [25]. Between the space for God and an underworld space lies madyapada or mertyapada [26], the space for human habitation. This human habitation aims to maintain the balance between the upper and the lower worlds [24]. Therefore, the world is then distributed into three zones: the divine, middle and lower world.

In the Balinese belief, people have a vital spiritual role in maintaining and protecting the world. This role is based on the Balinese philosophy's personification called tri hita karana [25], [27]. The essence of this belief is a harmonious affiliation between God, human beings and the environment [28]. Thus, this belief creates other Balinese landscapes and architectural forms that were divided into three sections: God's upper world (swah loka), the intermediate human world (bwah loka) and the demonic world (bhur loka) [24], [25]. The tri loka concept then produces a human physical division called tri angga that consists of utama, madia and nista or the head, body and legs. Utama or the head means high, lofty, or most sacred value, madia or the body means middle or neutral and nista or the legs means below or most profane value [17], [29].

\section{The House of God and the House of a King}

The tri loka and tri angga concepts that produce three hierarchy values in Bali's spatial planning and form have become a guideline for Balinese to design their architectural practices. The utama zone is for God and ancestors; the madya zone is for human being; and the nista zone maintains the relationship with the environment. As a place for God and ancestors, the utama zone was designed with the utama form and pattern. Balinese used special material such as palm fibre called $d u k$ for roof or sandalwood for many parts of shrines. In this part, there have also been many notable buildings, such as a meru that functioned as a place of worship to God or ancestors [30]. In the royal family of Puri Gianyar, the main zone for praying to God and ancestors called Merajan Agung Beng is around 500 meters north of the palace. The merajan agung is located in Beng Village, the location of the last palace of the Dewa Manggis Kuning, the founder 
of Gianyar Kingdom, before being moved to the current location by his successors.

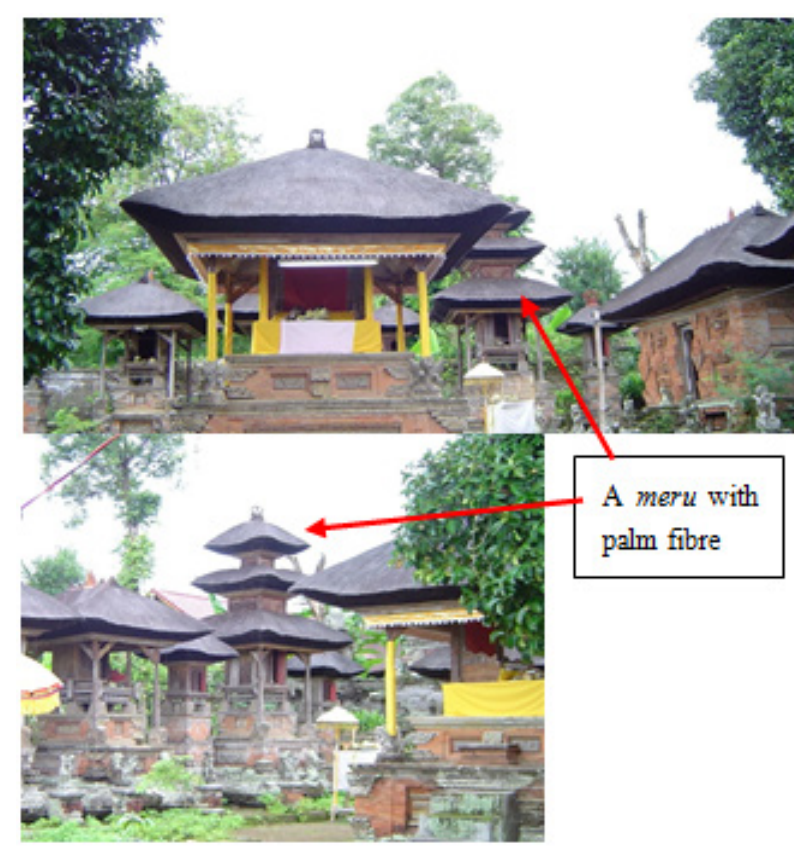

Figure 1. The shrines in Merajan Agung Beng using palm fibre roof

As a place for God and ancestors, the merajan agung consists of many buildings related to religious ceremony activities. A meru is a symbol of stratified heavens represented by the pagoda-like roofs called tumpang [13]. The high pagoda-like wood structure is built on stone platforms, usually with an odd number of superimposed receding roofs made of thick layers of $d u k$, the everlasting and costly fibre of the sugar palm [13]. This sacred building roof model is never used for domestic buildings, such as bales in a house and traditional village buildings. Gianyar people did not want to be equal (memada-mada) with God and their ancestors, so they tried to create special forms and models, and to use special materials for the sacred buildings. The roof of a meru and other shrines were constructed from palm fibre called $d u k$ (Figure 1). This material had never been used for domestic activities buildings called bale in a house called geria, jero and umah or palace called puri. The materials for such bales are usually used roof tile or reeds. This phenomenon presents that the Balinese used a hierarchy of building forms and models having symbolic values. For Gianyar people, this hierarchy was used to honour God as the world's creator; and respect ancestors who have inherited a noble culture.

The honour to God was also expressed from the form of the main gate called kori agung. The kori agung in the merajan agung as the house of God for the royal family used a combination between bricks and sandstones curved. The royal family wanted to present their honour to God and their ancestors by constructing a better main gate than their royal family house called puri. The high of the kori agung in the family temple is $7.5 \mathrm{~m}$ that is higher $(7 \mathrm{~m})$ than the one in the family royal house. The roof of the kori agung in the merajan agung (Figure 2a) was stratified into three-level while the roof of the kori agung in the palace was just one level (Figure 2b). The size and forms present that the royal family places the house for God is higher level than the house for the king. Even though the form of architecture presents the owner's social status, Gianyar people still use the word "memada-mada" as guidance to design and construct architectural practices. They placed God and ancestors in a special zone that had better quality than the quality for them. The guidance of memada-mada was also demonstrated in the number of steps of the stair. The merajan agung, like the house for God, has nine steps that were more than the steps' number in the palace having six steps. 


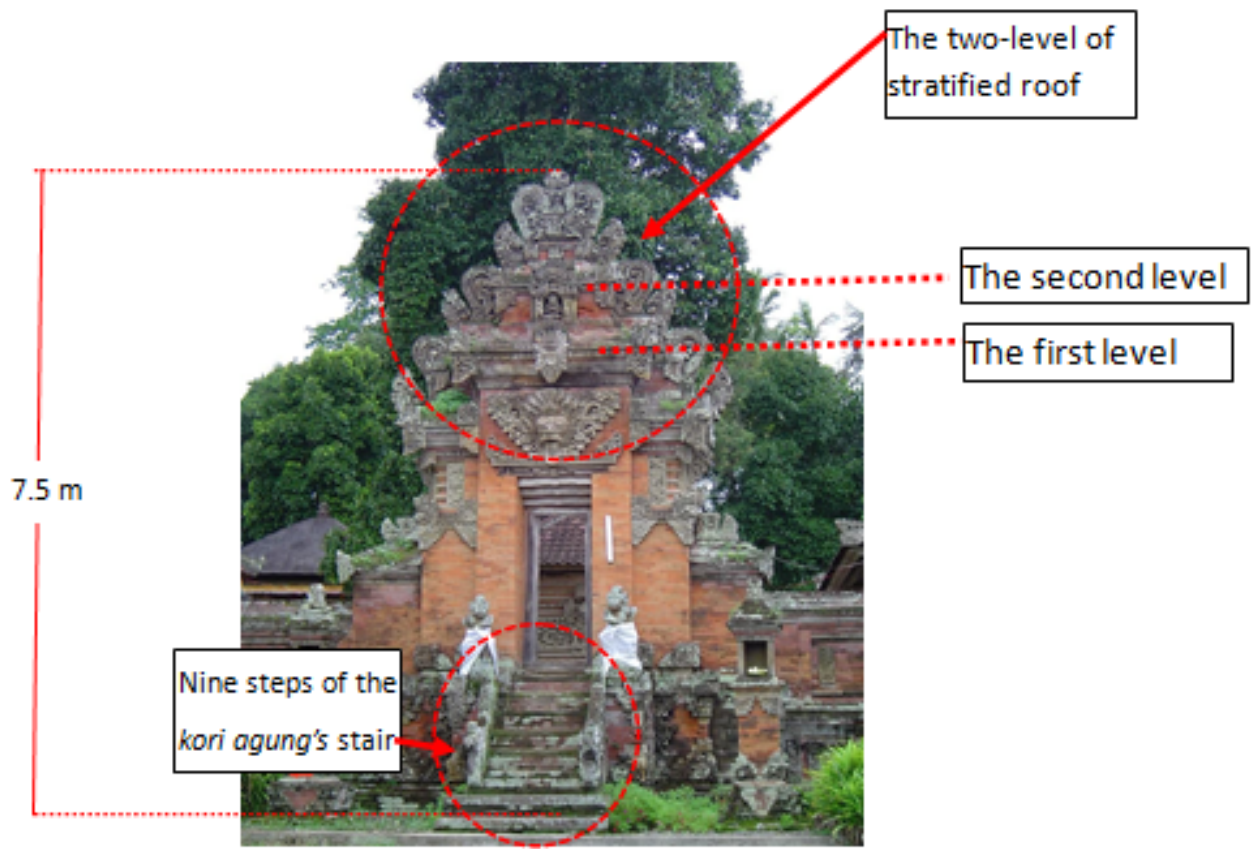

a. The kori agung in the royal family's temple

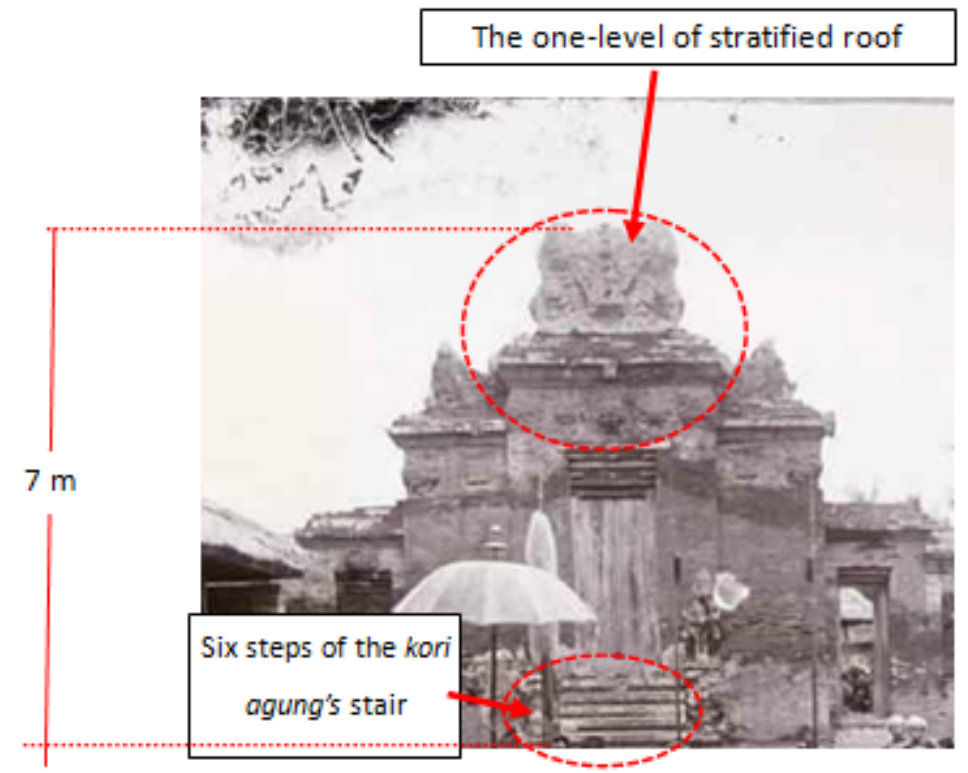

b. The kori agung in the royal house (Puri Gianyar) [31]

Figure 2. The kori agungs for the house of God (above) and the house of king (below)

\section{Political Power and Local Ethic Wisdom in the Balinese Architecture}

As the patron in its territory, the royal family house was different from other buildings. The form of the kori agung presented the majesty and social status of the owner. Compared with other family houses from non-royal families, the kori agung of the king's house represented that the owners had higher social status among the people in Gianyar [32]. This status was presented from symbolic form includes all forms of prestige, status, authority and legitimacy. Particularly related to legitimacy, symbolic capital was an effort to preserve and increase social recognition by reproducing the most suitable perceptual schemes to produce symbolic actions that were later inherited from generation to generation [33]. The gates were made of a mix of red brick and sandstone. Bricks were usually used for the main structure, while the ornaments were usually made of sandstone.

The gate has become a historic building, which has grown into major architectural works of art that stem from their function as profound symbolism of the institution's power and not just as aesthetic constructions. In this term, a new architectural production has been designed using 
selectively recombined several elements of existing knowledge into a new model [34]. However, this combination should not neglect the architectural art's structural basis since it depends mainly on its emblematic and iconographic power. After a thorough understanding of this connection and the possibility of a genuine political philosophy of architecture, the political position of architecture becomes more apparent [35]. In their respective territories, each palace has become an exemplary centre and patron of culture, and the art and rituals flourished in the palace and its surrounding villages. Palaces also have carried out state rituals within their territories to express their superiority to express their differences of status [14], [36]. The palaces have tried to build their own identity in their territory to express their limits and superiority. They have been expressed, and boundaries have been created with others.

The ruler of Gianyar has brought forth a new architectural model for the main gate of the palace to represent their culture and power. This creativity process uses people's ability to generate new ideas that are novel and valuable [37]. It would be essential to consider a site or system relevant to create an innovative product [38]. Creativity involves making something new using the old, making new connections, and being open to new and unexpected ideas [39]. Creativity can be thought of as the ability to put together elements or be thought of as the willingness to discover something new. However, pragmatism must also be considered for originality [40]. This phenomenon illustrates that political power has played an essential role in the design. In this term, architecture plays a significant social role in reflecting and exemplifying its time's cultural content [35]. Architectural productions have the power to communicate meaning and significance. There are monuments such as puri where a ruler can be displayed as a more explicit political statement. By studying the rulers' motivations, we can see that some buildings and spaces were constructed to create prestige, power and excitement.

However, memada-mada being a traditional moral ethic has already been moral guidance and influenced the architecture productions in Gianyar. After being conquered by Majapahit, Bali was led by the only Klungkung as the representation of the Majapahit Kingdom in Bali, and other palaces such as Badung, Bangli, Tabanan, Karangasem and Gianyar were classified as secondary independent palaces [14]. Even though Klungkung was recognized as Bali's leader, secondary independent palaces, especially Gianyar, often had disagreements with each other and it was not uncommon to have open wars with Klungkung [31]. This condition was because Klungkung was more recognized as a spiritual leader and because of heredity. In this case, Klungkung's position towards other kingdoms was not as Bali's ruler but as an elder palace while other palaces remained independent in regulating their territory [41]. In this case, as secondary independent palaces, they managed their territory and had the authority to make any policy. In order to express their shortcomings and dominance over customs, cultural practices and architectural styles that vary from others, secondary palaces attempted to create an identity of their own. One of the main components that articulate the distinctive identity in a specific region was an architectural practice.

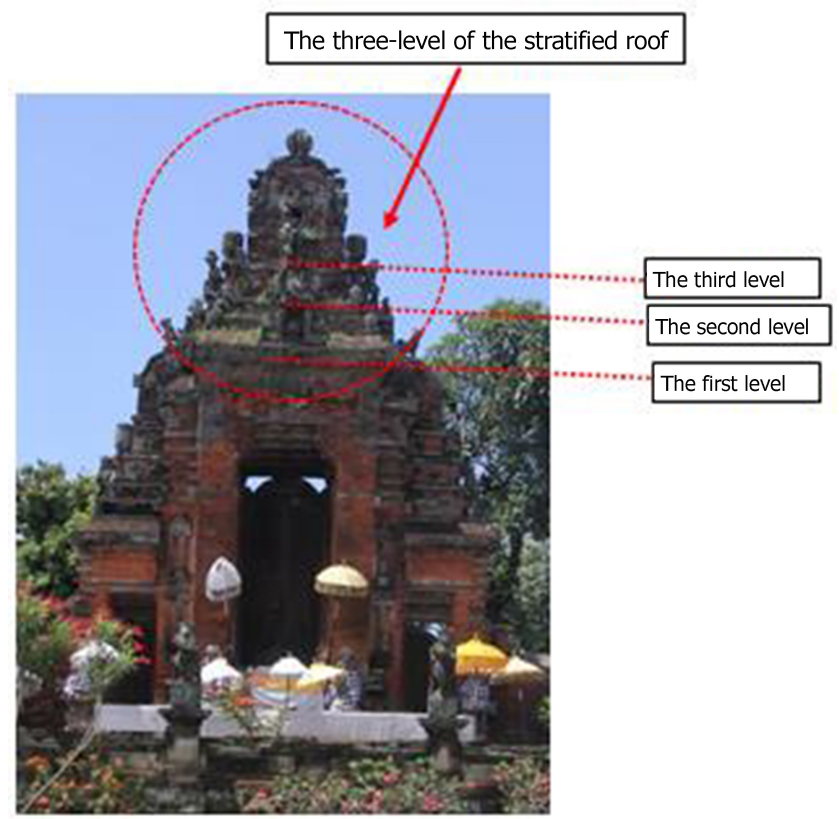

Figure 3. The Photograph of the kori agung of Klungkung Palace

Since the authorities have changed to build a strong identity and a monument to indicate their restoration of previous models of domination and subordination [42], the king of Gianyar produced a different architectural style with Klungkung, the primary palace in Bali, to demonstrate its power in its territory. On the other hand, the new architecture model was a lower hierarchy than the Klungkung architecture. As the secondary palace in Bali, the kori agung in Puri Gianyar was designed lower level than the kori agung of Puri Klungkung was believed as the leader of kingdoms in Bali [14]. While the roof of the kori agung in Gianyar was without stratified roof level (Figure 2b), the kori agung in Klungkung had three stratified roof levels (Figure 3). The kori agung of Klungkung is higher $(12 \mathrm{~m})$ (Figure $4 \mathrm{a})$ than the kori agung of Gianyar (7 m) (Figure $4 \mathrm{~b}$ ). These kori agung's sizes demonstrated that Puri Klungkung has a higher status than the status of Puri Gianyar. The King of Gianyar still honoured and respected the King of Klungkung. The latter was the primary kingdom of Bali. On the other hand, the kingdom of the king of Gianyar's ancestors, even though the power authority tended to build substantial monumental architectural production to demonstrate the power of the regime [43], the king tried to respect Puri Klungkung by building a lower level of kori agung. The King of Gianyar had the opportunity to 
restructure cultural commodities that gave the authorities the power to territorialize space and deal with political affairs [44]. However, the king of Gianyar used the traditional wisdom ethic to not be memada-mada as a guideline for the Gianyar Palace design.

Based on the memada-mada, the Gianyar authority presented its supremacy through the creation of architectural identity. Gianyar attempted to create a unique form of architecture to show their identities. However, the architectural production built was lower level than the architectural landmark of Klungkung. This phenomenon presents a monument telling the place's history with political and social authority [35], [45]. The choice of the kori agung's shape and creation has demonstrated an architectural relationship reflected in many architectural aspects, such as architectural styles, scale, form, and ornaments [3],[4]. The size and forms of the monument represented the strength of government and the authority's social level among the other authority in Bali. The size and form of architecture influenced people's actions and behaviours through memorial architecture [46],[45]. Therefore, the form of kori agung Puri Gianyar demonstrates that the memorial architecture in a territory was influenced not only by the authorities' political power in their territory but also by memada-mada as a pearl of traditional ethic wisdom and social status among puris in the Balinese community.

\section{Conclusions}

Political agenda and social strata have a historical and related impact on cultures and architectural production. A political institution that demonstrates an institution's superiority has led to the creation of many new traditions that demonstrate its power. As a patron, the architectural productions in a puri, including the kori agung, have become unique amongst surrounding buildings. The shape of the kori agung emphasises and demonstrates the owner's wealth, prestige and authority. The kori agung is representative of the social status of the family head within their lineage. In a symbolic form, there are forms of status and prestige, authority and legitimacy.

However, memada-mada, a traditional moral ethic, has already influenced architectural production in Gianyar. The buildings in Puri Gianyar have tried to present their authorities in its territory, but the forms have been lower level than the building in the royal temple and building form of Puri Klungkung, the leader of Bali kingdoms in pre-colonialism in Bali. For Balinese kingdoms, power is not always about managing their territory and building the monumental constructions. Instead, the power is about how they honour and respect God and create an architectural production based on the Balinese architectural hierarchy and social strata.

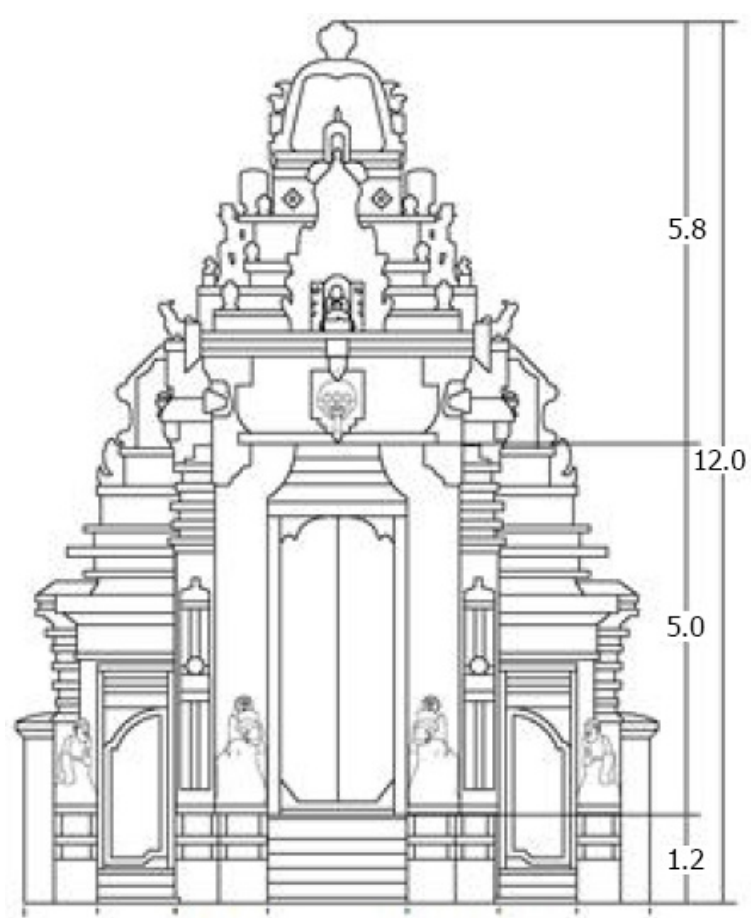

a. The Kori Agung Klungkung

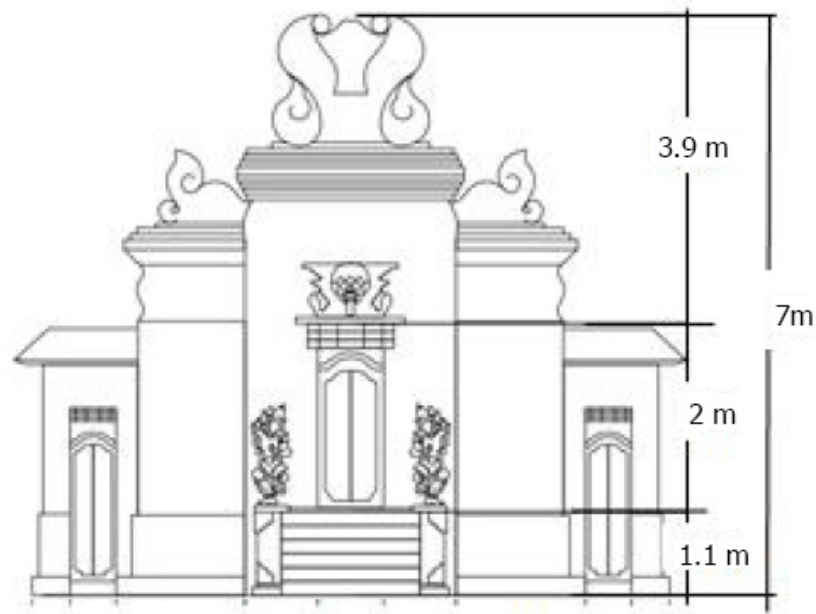

b. The Kori Agung Gianyar

Figure 4. Comparison the kori agung of Klungkung Palace (right) and Gianyar Palace (left). 
The production of architecture has been related to the political relation in Bali. Even though Gianyar has its authority in its territory, the status of Gianyar as secondary independent palaces has encouraged the Gianyar authority to give respect to Klungkung as the heir of the Majapahit kingdom in Bali. This phenomenon has demonstrated that political power is not the single entity influencing architecture to present power authority. There is the other local moral ethic of Balinese that also affects the architectural forms. Social strata and moral ethics have become guidance for the secondary independence palace including Gianyar to present its respect to Bali's spiritual leader and their ancestors.

\section{REFERENCES}

[1] S. Kraft, "Architecture is the mirror of every historical moment, we can see our time reflex on the buildings of our cities." Interview with Daniele del Nero," deconarch.com, 2013.

http://www.deconarch.com/architecture-is-the-mirror-of-eve ry-historical-moment-we-can-see-our-time-reflex-on-the-bui ldings-of-our-cities-interview-daniele-del-nero/.

[2] E. Shils, Tradition. University of Chicago Press, 1981.

[3] A. S. Ismail and D. Alice, "Discourse of Democratic Architecture in Malaysia: An Analysis of Putrajaya Government Building in Comparison to Parliament Building," Engag. Malaysia Mod., vol. 50, 2008.

[4] A. S. Ismail, "Architecture as an Expression of Political Ideology," Fac. Built Environ. Univ. Teknol. Malaysia, Malaysia, 2014.

[5] A. Al-Kawakibi, Tyranny's Natures and Slavery Wrestler (tabayiealaistibdadwamasariealaistiebad). Cairo, Egypt: Egyptian General Book Authority, 2011.

[6] P. Ferschin and A. Gramelhofer, "Architecture as information space," Proc. Int. Conf. Inf. Vis., vol. 8, no. August 2004, pp. 181-186, 2004, doi: 10.1109/iv.2004.1320142.

[7] I. N. Pursika and I. K. Sudiatmaka, "Kebertahanan Tradisi Manak Salah Pada Masyarakat Padang Bulia," Semin. Nas. Ris. Inov. Ke-4, pp. 664-674, 2016.

[8] I. G. A. A. C. Dewi, "Manak Salah Dalam Tradisi Lokal Di Desa Pakraman Julah Kabupaten Buleleng," Kamaya J. Ilmu Agama, vol. 1, no. 1, pp. 49-68, 2018.

[9] G. N. G. Dipta, "Media Informasi Tradisi Manak Salah (Bayi Kembar Buncing) di Desa Padangbulia-Buleleng Bali berbasis Video," UNivrsitas Pendidikan Ganesha Singaraja, 2020.

[10] I. D. G. A. D. Putra, M. Lozanovska, and R. Fuller, "A methodology to evaluate the transformation of traditional balinese houses as a consequence of Tourism," Archnet-IJAR, vol. 11 , no. $1,2017$.

[11] I. D. G. A. D. Putra, M. Lozanovska, and R. Fuller, "From spiritualistic toward more pragmatic pattern: Re-ordering
Balinese houses and viability of the household traditions in tourism economy," J. Archit. Urban., vol. 43, no. 1, 2019, doi: 10.3846/jau.2019.3692.

[12] L. E. A. Howe, "Hierarchy and equality; Variations in Balinese social organization," Bijdr. tot taal-, land-en Volkenkd. / J. Humanit. Soc. Sci. Southeast Asia, vol. 145, no. 1, pp. 47-71, 2020, doi: 10.1163/22134379-90003268.

[13] M. Covarrubias, Island of Bali. Singapore: Periplus Editions, 2015.

[14] C. Geertz, Negara. Princeton University Press, 1980.

[15] N. K. A. Dwijendra and I. P. G. Suyoga, "Analysis of symbolic violence practices in balinese vernacular architecture: A case study in Bali, Indonesia," Int. J. Innov. Creat. Chang., vol. 13, no. 5, pp. 184-194, 2020.

[16] I. G. Parimartha, I. K. Ardhana, A. A. B. Wirawan, I. B. R. Putra, and I. B. G. Putra, "Sejarah Bali Pertengahan Abad XIV-XVIII," in Sejarah Bali dari Prasejarah hingga Modern, Third Edit., I. W. Ardhika, I. G. Parimartha, and A. A. B. Wirawan, Eds. Denpasar: Universitas Udayana Press, 2018, pp. 261-354.

[17]I. N. Gelebet, Arsitektur Tradisional Bali (Balinese Traditional Architecture). Denpasar: Bappeda Bali, 1998.

[18] I. M. Adhika and I. D. G. A. D. Putra, "Reinvigorating cultural landscapes for planning cultural tourism in Bali," Geoj. Tour. Geosites, vol. 33, no. 4, pp. 1462-1469, 2021, doi: $10.30892 /$ gtg.334sp103-594.

[19] N. K. A. Dwijendra, "From tradition to modernization in morphological process of indigenous settlement patterns in Bali, Indonesia," Int. J. Adv. Sci. Technol., vol. 29, no. 8 Special Issue, pp. 856-868, 2020.

[20] I. D. G. A. D. Putra, I. B. G. Wirawibawa, and M. W. Satria, "Spatial orientation and the patterns of the traditional settlement in the eastern Bali: Investigating new tourism atractions," Geoj. Tour. Geosites, vol. 29, no. 2, 2020, doi: 10.30892/gtg.29218-493.

[21] I. D. G. A. D. Putra, I. M. Adhika, A. A. G. A. Yana, "Reviving Cultural Tourism in Kendran Bali Indonesia: Maintaining Traditional Architecture and Developing Community-based Tourism," Civil Engineering and Architecture, Vol. 9, No. 2, pp. 328 - 338, 2021, DOI: 10.13189/cea.2021.090206.

[22] I. G. N. W. Hardy, B. Setiawan, and B. Prayitno, "Pengaruh Sistem Catur Wangsa terhadap Perwujudan Tata Spasial Kota Peninggalan Kerajaan Hindu di Bali: Kasus Kota Karangasem," J. Kaji. Bali, vol. 06, no. 02, pp. 79-96, 2016.

[23] I. P. G. Suyoga, "Pengaruh Istilah Griya, Puri, dan Jero, sebagai Nama Kompleks Perumahan Masa Kini: Perspektif Pergulatan Identitas.," J. Patra, vol. 1, no. 1, pp. 74-78, 2019.

[24] A. Hobart, U. Ramseyer, and A. Leemann, The people of Bali. Massachusetts: Blackwell Publishers Ltd, 2001.

[25] F. Eiseman Jr, Sekala and niskala: essays on religious, ritual and art, vol. I. Singapore: Periplus Editions, 1989.

[26] J. Swellengrebel, "Introduction," in Bali: studies in life, thought, and ritual, J. Swellengrebel, Ed. Nethelands: Foris 
Publication Holland, 1984, pp. 1-76.

[27] H. Kagami, "Balinese traditional architecture in process, the Little World Museum of Man.” Inuyama, 1988.

[28]A. A. G. R. Dalem, "Filosofi tri hita karana dan implementasinya dalam industri pariwisata," in Kearifan lokal dalam pengelolaan lingkungan hidup, UPT Penerbit and Pusat Penelitian Lingkungan Hidup Universitas Udayana, Denpasar, pp. 81-94., I. S. \& I. A. (eds) AAGR Dalem, IW Wardi, Ed. Denpasar: UPT Penerbit and Pusat Penelitian Lingkungan Hidup Universitas Udayana, 2007, pp. 81-94.

[29] I. G. M. Putra, Perumahan. Denpasar: Jurusan Arsitektur Universitas Udayana Bali, 1984.

[30] N. K. A. Dwijendra, "Meru as a hindu sacred building architecture with a high roof and resistant to earthquakes in Bali, Indonesia," Civil Engineering and Architecture, Vol. 8, No. 3, pp. $350 \quad-\quad 358, \quad 2020$, DOI: $10.13189 /$ cea.2020.080319.

[31] Mahaudiana, Babad Manggis Gianyar. Gianyar: A.A. Gde Thaman, 1968.

[32] I. D. G. A. D. Putra and I. B. G. Wirawibawa, "The Balinese Palaces in Gianyar: Representing Authority Power and Creating Territorial Identity," Int. J. Innov. Creat. Chang., vol. 14, no. 8, pp. 132-150, 2020.

[33] P. Bourdieu, The Logic of Practice. Stanford: Stanford University Press., 1991.

[34] T. Taura and Y. Nagai, "Creativity in innovation design: The roles of intuition, synthesis, and hypothesis," Int. J. Des. Creat. Innov., vol. 5, no. 3-4, pp. 131-148, 2017, doi: $10.1080 / 21650349.2017 .1313132$.

[35]D. Milne, "Architecture, Politics and the Public Realm," Archit. Polit. Public Realm, vol. 5, pp. 131-146, 1981.
[36]H. G. C. S. Nordholt, "Bali: Colonial conceptions and political change 1700-1940. From shifting hierarchies to'fixed'order," 1986.

[37] S. Jagtap, "Design creativity: refined method for novelty assessment," Int. J. Des. Creat. Innov., vol. 7, no. 1-2, pp. 99-115, 2019, doi: 10.1080/21650349.2018.1463176.

[38] M. Csikszentmihalyi, "Flow and the psychology of discovery and invention," HarperPerennial, New York, vol. 39, 1997.

[39] A. Maley, "Creative approaches to writing materials," in Developing materials for language teaching, Brian Tomlinson, Ed. London: Bloomsbury Academic, 2003, pp. 183-198.

[40] A. Maley and R. Bolitho, "Creativity," ELT J., vol. 69, no. 4, pp. 434-436, 2015.

[41] I. W. Ardika, I. G. Parimartha, and A. A. B. Wirawan, Sejarah Bali: dari prasejarah hingga modern. Udayana University Press, 2013.

[42]A. Krivolap, "Parad oznachayushikh: belorusskiy opyt vizualizatsii Dnya nezavisimosti [A Parade of Signifiers: The Belarusian Experience of the Visualization of Independence Day].," in Belarusian Format: Invisible Reality, Almira Ousmanova, Ed. Vilnius: EHU, 2008, pp. 368-396.

[43]D. Hollier, Against architecture: the writings of Georges Bataille. mit Press, 1989.

[44] A. Sarna, "Politika i simvol. Strategii politicheskogo marketinga v Belarusi 2004-2006 gg.[Politics and Symbol: Strategies of Political Marketing in Belarus 2004-2006]," Belarusian Format Invis. Reality. Almira Ousmanova, ed, pp. 232-264, 2008.

[45] W. H. Coaldrake, Architecture and authority in Japan. Psychology Press, 1996.

[46] L. B. Alberti, On the art of building in ten books. Mit Press, 1988. 